\title{
Mycobacterium madagascariense sp. nov.
}

\author{
J. KAZDA, ${ }^{1 *}$ H.-J. MÜLLER, ${ }^{2}$ E. STACKEBRANDT, ${ }^{3}$ M. DAFFE, ${ }^{4}$ K. MÜLLER, ${ }^{5}$ AND C. PITULLE ${ }^{6}$ \\ Division of Veterinary Medical Microbiology, Research Institute of Borstel, Institute for Experimental Biology \\ and Medicine, D-2061 Borstel, Germany ${ }^{1}$; Molecular Biology Section, Bernhard Nocht Institute for Tropical \\ Medicine, Hamburg, Germany'; Department of Microbiology, Centre of Bacterial Diversity and Identification, \\ University of Queensland, St. Lucia, Brisbane, Australia ${ }^{3}$; Center for Research of Biochemistry and Cell \\ Genetics, Centre National de la Recherche Scientific, Toulouse, France ${ }^{4}$; and Institute for Botany ${ }^{5}$ and \\ Institute for General Microbiology, ${ }^{6}$ Christian-Albrechts-University, Kiel, Germany
}

\begin{abstract}
Strains of a new type of rapidly growing, scotochromogenic mycobacterium were isolated from sphagnum vegetation in Madagascar. These strains grew at 31 and $22^{\circ} \mathrm{C}$ but not at $37^{\circ} \mathrm{C}$, possessed catalase, acid phosphatase, and arylsulfatase activities, split urea and pyrazinamid, hydrolyzed Tween, and produced acid from glucose, L-arabinose, fructose, mannitol, rhamnose, sorbitol, xylose, and trehalose. Furthermore, they metabolized iron and possessed putrescine oxidase activity but did not reduce nitrate. The internal similarity level of the strains, as determined by taxonomic methods, was $92.50 \%$. The phylogenetic relationships of strain $\mathrm{P2}^{\mathrm{T}}$ ( $\mathrm{T}=$ type strain) with members of the genus Mycobacterium, as determined by comparing the 16S rRNA primary structure of this strain with the 16S rRNA primary structure of this stain with the 16S rRNA primary structures of 41 other mycobacterial species, indicated that strain $\mathrm{P2}^{\mathrm{T}}$ belongs to a separate line of descent within a cluster that includes Mycobacterium phlei, Mycobacterium smegmatis, Mycobacterium confluentis, Mycobacterium flavescens, and Mycobacterium thermoresistibile. Hence, the new strains are considered members of a new species of nonpathogenic, rapidly growing mycobacteria, for which we propose the name Mycobacterium madagascariense. Strain P2 is the type strain; a culture of this strain has been deposited in the American Type Culture Collection as strain ATCC 49865.
\end{abstract}

In August 1988, 18 samples of sphagnum vegetation were collected in the southeast coastal region of Madagascar and were examined for mycobacteria; $83.3 \%$ of these samples contained mycobacteria (16). A group of four strains that were isolated from three different biotopes exhibited high levels of internal similarity. The properties of these strains differed significantly from the properties of other species of rapidly growing mycobacteria.

\section{MATERIALS AND METHODS}

Bacterial strains. Strains $\mathrm{P} 1, \mathrm{P} 2^{\mathrm{T}}$ ( $\mathrm{T}=$ type strain), $\mathrm{P}$, and P4 were isolated from three of the five sphagnum biotopes examined between Taolanaro and Sainte-Luce in the southeast coastal region of Madagascar. Strain P1 was isolated from Sphagnum gradiente (Warnst.), strain $\mathrm{P} 2^{\mathrm{T}}$ was isolated from Sphagnum obtusiusculum (Lindb.), and strains P3 and P4 were isolated from Sphagnum balfourianum (Warnst.).

Methods. Colony morphology and the ability to grow at various temperatures $\left(22,31\right.$, and $\left.37^{\circ} \mathrm{C}\right)$ were determined for the strains which we tested during 1 week of incubation on Löwenstein-Jensen medium and Middlebrook 7H10 agar, which were inoculated with approximately $10^{-2} \mathrm{mg}$ (wet weight) of mycobacteria per plate. Pigment production in the dark and photoactivity during 1 week of incubation were also determined $(6,24)$.

The following characteristics were also determined: growth on MacConkey agar (17); resistance to $0.2 \%$-aminosalicylic acid (23), $20 \mu \mathrm{g}$ of sodium azide per $\mathrm{ml}, 250 \mu \mathrm{g}$ of hydroxylamine per $\mathrm{ml}, 1 \%$ sodium deoxycholate, $3 \%$ sodium chloride, and $0.01 \%$ sodium nitrite $(21,22,24)$; iron uptake (20); nitrate reduction (2); arylsulfatase activity in 3 days

\footnotetext{
* Corresponding author.
}

(11); acid phosphatase $\left(4 \mathrm{~h}, 31^{\circ} \mathrm{C}\right)(9)$, acetamidase, benzamidase, urease, isonicotinamidase, nicotinamidase, pyrazinamidase, salicylamidase, allantoinase, succinamidase, and malonamidase activities (1); and putrescine oxidase production (3). Acid production from carbohydrates (glucose, L-rhamnose, D-xylose, L-arabinose, D-galactose, D-mannitol, D-sorbitol, inositol, dulcitol, trehalose, and $D$-fructose) was tested during 3 weeks of incubation (7). The utilization of fumarate, succinate, citrate, malonate, oxalate, benzoate, hippurate, and 1-propanol as sole carbon sources and the utilization of acetamide, benzamide, and trimethylene diamine as sole nitrogen and carbon sources were determined by using the methods described by Tsukamura (25). A test to determine the degradation of salicylate was also performed (23).

Phylogenetic analysis. A phylogenetic analysis of strain $\mathrm{P} 2^{\mathrm{T}}$ (= madagascar ${ }^{\mathrm{T}}$ ) was performed recently (18). After this analysis was performed, Mycobacterium confluentis was described, and the 16S rRNA sequence was published (10). Since $M$. confluentis and strain $\mathrm{P} 2^{\mathrm{T}}$ are both members of the same phylogenetic cluster, the position of strain $P 2^{\mathrm{T}}$ was defined. Pairwise evolutionary distances (expressed as the estimated numbers of changes per 100 nucleotides) were computed from percentages of similarity by using the correction of Jukes and Cantor (8). A phylogenetic tree was constructed from the distance matrix by using the algorithm of De Soete (5). Sequence alignment and data analysis were done by using a SUN Sparc workstation.

Lipid analyses. Lipid analyses were carried out for all strains by using cells that were scraped from LöwensteinJensen slants. Free lipids were extracted from cells with $\mathrm{CHCl}_{3}-\mathrm{CH}_{3} \mathrm{OH}(1: 1$, vol/vol) and were analyzed by thinlayer chromatography, using $\mathrm{CHCl}_{3}-\mathrm{CH}_{3} \mathrm{OH}-\mathrm{H}_{2} \mathrm{O}$ (30:8:1, 30:12:1, and 65:25:4, $\mathrm{vol} / \mathrm{vol} / \mathrm{vol})$ and $\mathrm{CHCl}_{3}-\mathrm{CH}_{3} \mathrm{OH}(99: 1$ and 90:10, vol/vol) as eluents. The defatted cell residues 
were saponified and converted to methyl esters, and mycolate patterns were determined as previously described (12, 13). Alternatively, scraped cells were saponified and converted to methyl esters, and nonhydroxylated esters were examined by gas chromatography, using a Perkin-Elmer model $8310 \mathrm{~B}$ apparatus, a $1-\mathrm{m}$ column packed with $3 \%$ OV-1, and nitrogen as the carrier gas. To determine the compositions of the chains in position 2 of the mycolates, pyrolytic conditions were used, with the injector temperature raised from 300 to $400^{\circ} \mathrm{C}$ (4).

For the pathogenicity tests, a 4-day-old culture of strain $P 2^{\mathrm{T}}$ was used. Four rabbits were injected intravenously with $10 \mathrm{mg}$ (semiwet weight) of bacteria, five white mice were injected with $1 \mathrm{mg}$ intravenously, and four guinea pigs were injected with $10 \mathrm{mg}$ subcutaneously. After 15 weeks, the animals were sacrificed and autopsied (14).

Numerical analysis. On the basis of the results of a comparison of 51 properties, the level of internal similarity of strains P1, P2 ${ }^{\mathrm{T}}, \mathrm{P} 3$, and P4 was determined (19). A total of 43 properties of 22 species of rapidly growing mycobacteria were determined and compared with the properties of strain $\mathrm{P}^{\mathrm{T}}$. All of the data were converted to the simple binary form (i.e., 1 or 0 ) for analysis; both positive and negative matches were used (19).

\section{RESULTS AND DISCUSSION}

The cells of strains $\mathrm{P} 1, \mathrm{P} 2^{\mathrm{T}}, \mathrm{P} 3$, and $\mathrm{P} 4$ grown on Löwenstein-Jensen medium and on Middlebrook 7H10 agar were rod shaped ( 0.6 by 1.2 to $1.5 \mu \mathrm{m})$, often polymorphic, gram positive, and acid-alcohol fast and formed clumps but not cords or cross bands. Spores, capsules, true branching, and aerial hyphae were not observed. On Löwenstein-Jensen medium, all of the strains were eugonic and smooth, and yellow- or orange-pigmented colonies were produced when cultures were incubated at temperatures of 22 and $31^{\circ} \mathrm{C}$. At $31^{\circ} \mathrm{C}$ growth was observed after 3 days; at $22^{\circ} \mathrm{C}$ growth was observed after 7 days. No growth occurred at 37,42 , or $45^{\circ} \mathrm{C}$. Smooth, glistening, yellow or orange colonies that were 1 to $2 \mathrm{~mm}$ in diameter and had entire margins developed on Middlebrook 7H10 agar from dilute inocula after 3 days of incubation at $31^{\circ} \mathrm{C}$. Properties of the strains are shown in Table 1 . The strains created a homogeneous group that had a level of internal similarity of $92.50 \%$.

The whole-cell mycolate patterns (Table 2) confirmed the homogeneity of the taxon, but the same mycolate types are also present in several rapidly growing mycobacterial species $(4,12,15)$. However, on the basis of the nature of the major pyrolysis esters (docosanoate), only three species (Mycobacterium aurum, Mycobacterium neoaurum, and Mycobacterium gadium) had to be compared with the members of the new taxon. Moreover, when the nonhydroxylated fatty acid methyl esters were considered, $M$. aurum, $M$. neoaurum, and $M$. gadium accumulated significant amounts of 2,4-dimethyl docosanoate, as did strains $\mathrm{P} 1, \mathrm{P} 2^{\mathrm{T}}, \mathrm{P} 3$, and P4 (26).

When testing for pathogenicity, we found that strain $\mathrm{P} 2^{\mathrm{T}}$ produced neither organic nor local lesions in infected rabbits, guinea pigs, or mice.

On the basis of a comparison of the 16S rRNA of strain $\mathrm{P}^{\mathrm{T}}$ and 57 reference sequences from 41 previously described species of the genus Mycobacterium, we concluded that strain $\mathrm{P}^{\mathrm{T}}$ (listed as strain madagascar in reference 18) is a nonthermotolerant member of a group of mycobacteria that exhibit increased thermotolerance (18). Recently, $M$. confluentis has been shown to be a member of this group,
TABLE 1. Characteristics of strains $\mathrm{P} 1, \mathrm{P} 2^{\mathrm{T}}, \mathrm{P} 3$, and $\mathrm{P} 4$

\begin{tabular}{|c|c|}
\hline Characteristic & $\begin{array}{l}\% \text { of strain } \\
\text { giving posi } \\
\text { tive reactio }\end{array}$ \\
\hline Pigment production in the dark $\ldots \ldots \ldots \ldots \ldots \ldots \ldots \ldots \ldots \ldots \ldots$ & 100 \\
\hline 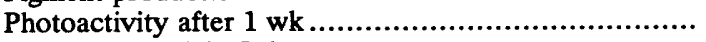 & 0 \\
\hline Growth at $22^{\circ} \mathrm{C}$ in 7 days ....................... & 100 \\
\hline 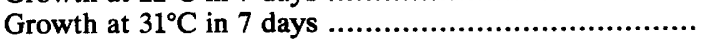 & 100 \\
\hline 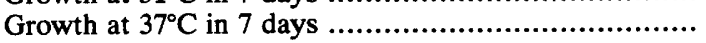 & 0 \\
\hline \multicolumn{2}{|l|}{ Enzymatic activities } \\
\hline Acid phosphatase $\left(31^{\circ} \mathrm{C}, 4 \mathrm{~h}\right) \ldots \ldots \ldots$. & 100 \\
\hline Acid phosphatase $\left(70^{\circ} \mathrm{C}, 30 \mathrm{~min}\right) \ldots$. & $25^{a}$ \\
\hline Arylsulfatase $(3$ days $)$ & 100 \\
\hline 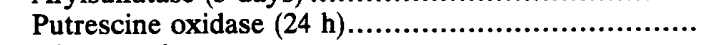 & $75^{b}$ \\
\hline 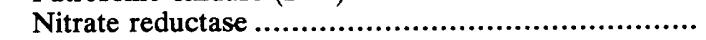 & 0 \\
\hline Tween hydrolysis ( 10 days) .. & 100 \\
\hline 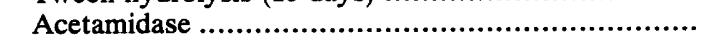 & 0 \\
\hline 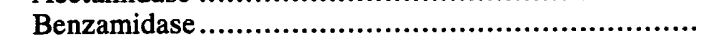 & 0 \\
\hline Urease & 100 \\
\hline 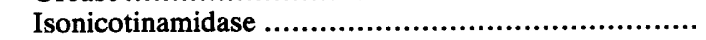 & 0 \\
\hline Nicotinamidase...... & $50^{c}$ \\
\hline Pyrazinamidase ............ & 100 \\
\hline Salicylamidase............. & 0 \\
\hline 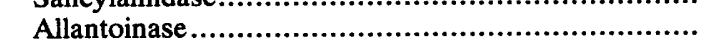 & $50^{c}$ \\
\hline (................................... & 0 \\
\hline 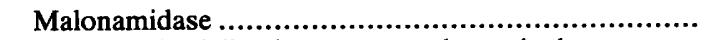 & 0 \\
\hline
\end{tabular}

Growth on the following compounds as single carbon sources:

Sodium benzoate

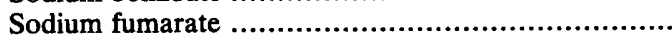

Sodium succinate

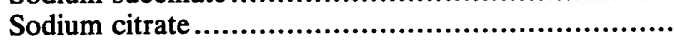

Sodium malonate .

Sodium oxalate.......

Sodium hippurate.

1-Propanol

Growth on the following compounds as single nitrogen and carbon sources:

Acetamide .

Benzamide

Trimethylene diamine .

Growth in presence of:

Hydroxylamine $(250 \mu \mathrm{g} / \mathrm{ml})$

Sodium azide $(20 \mu \mathrm{g} / \mathrm{ml})$.

$\mathrm{NaCl}(3 \%)$...

$\mathrm{NaNO}_{2}(0.1 \%)$

Growth on MacConkey agar .

Degradation of salicylate

Iron uptake

Acid production from:

D-Glucose.

L-Arabinose ...................................................

Dulcitol...

D-Fructose......

D-Galactose .

Inositol .

D-Mannitol .

L-Rhamnose.

D-Sorbitol.

Trehalose .....

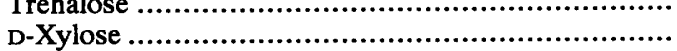

${ }^{a}$ Strain $\mathrm{P} 1$ was positive.

${ }^{b}$ Strain P4 was negative.

c Strains $\mathrm{P} 1$ and $\mathrm{P} 2^{\mathrm{T}}$ were positive

${ }^{d}$ Strain $\mathrm{P} 3$ was negative.

- Strains P1 and P3 were positive.

${ }^{f}$ Strains $\mathrm{P} 3$ and $\mathrm{P} 4$ were positive.

$\boldsymbol{g}$ Strain P1 was negative. 
TABLE 2. Mycolate types, major pyrolysis esters, and alcohol compositions of strains $\mathrm{P} 1, \mathrm{P} 2^{\mathrm{T}}, \mathrm{P} 3$, and $\mathrm{P} 4^{a}$

\begin{tabular}{|c|c|c|c|c|c|c|c|c|c|c|}
\hline \multirow[b]{2}{*}{ Strain } & \multicolumn{6}{|c|}{ Mycolate types } & \multicolumn{2}{|c|}{ 2-OH composition } & \multicolumn{2}{|c|}{ Major pyrolysis esters } \\
\hline & I & II & III & IV & $\mathrm{v}$ & VI & $\mathrm{C}_{18}$ & $\mathrm{C}_{20}$ & $\mathrm{C}_{22}$ & 2,4-Dimethyl \\
\hline P1 & + & - & - & $(+)$ & - & + & + & $(+)$ & + & + \\
\hline $\mathbf{P}^{\mathrm{T}}$ & + & - & - & $(+)$ & - & + & + & $(+)$ & + & + \\
\hline P3 & + & - & - & $(+)$ & - & + & + & $(+)$ & + & + \\
\hline P4 & + & - & - & $(+)$ & - & + & + & $(+)$ & + & + \\
\hline
\end{tabular}

${ }^{a}$ The mycolate types have been described previously (4). +, detected; -, not detected; $(+)$, minor compound.

which includes, in addition to strain $\mathrm{P}^{\mathrm{T}}$, Mycobacterium phlei, Mycobacterium smegmatis, Mycobacterium flavescens, Mycobacterium thermoresistibile, and the undescribed organism "Mycobacterium chromogen." A phylogenetic analysis of all of the members of this group and certain strains that were also included in the numerical phenetic study indicated that strain $\mathrm{P} 2^{\mathrm{T}}$ and $M$. confluentis are closely related (Table 3 and Fig. 1). The low level of nucleotide differences in the 16S rRNAs of these two organisms (as little as 1.9\%) is not unusual for fast-growing mycobacteria; similar low values have been found for $M y$ cobacterium diemhoferi, Mycobacterium obuense, and $M y$ cobacterium gilvum and for $M$. flavescens and $M$. smegmatis (Table 3).

Organisms that exhibit high levels of phenetic similarity to strain $\mathrm{P} 2^{\mathrm{T}}$ are less closely related phylogenetically (18) (Fig. 1). $M$. aurum appears to be more closely related to $M y c o$ bacterium vaccae, while the $M$. obuense-Mycobacterium chubuense- $M$. gilvum line and the $M$. neoaurum-M. diernhoferi line are two additional separate lines of descent that are equidistantly related to the group of thermotolerant species and their nonthermotolerant relatives. Apparently, the phenotypic similarities of the characteristics used in the numerical study do not reflect the levels of genetic relatedness of the organisms. $M$. gadium, which produced the same major pyrolysis esters as strain $\mathrm{P}^{\mathrm{T}}, M$. aurum, and $M$. neoaurum, is not phylogenetically related to members of the strain $\mathrm{P}^{\mathrm{T}}$ taxon. As shown elsewhere (18), $M$. gadium represents a separate line of descent within the radiation of mycobacteria and is closely related to the 21 slow-growing species which we investigated.

Taxonomic description of Mycobacterium madagascariense sp. nov. Mycobacterium madagascariense (mad'a.gas.car.i. en.se. M.L. adj. madagascariense, belonging to the island of Madagascar, the source of the strains). The description below is based on a study of four strains which share the characteristics shown in Table 1. Cells are gram-positive, acid-alcohol-fast, polymorphic rods ( 0.6 by 1.2 to $1.5 \mu \mathrm{m})$ which often form clumps but not cords or cross bands. Spores, capsules, and aerial hyphae do not occur. Colonies on Löwenstein-Jensen medium and on Middlebrook 7H10 agar are smooth, glistening with yellow or orange pigmentation, and 1 to $2 \mathrm{~mm}$ in diameter. The optimum growth temperature is $31^{\circ} \mathrm{C}$; no growth occurs at $37^{\circ} \mathrm{C}$ or above. Biochemical characteristics are shown in Table 1. Positive for pigment production, acid phosphatase activity $\left(31^{\circ} \mathrm{C}, 4\right.$ h), arylsulfatase activity, Tween hydrolysis, and urease and nicotinamidase activities. The strains metabolize iron and form acid from glucose, arabinose, dulcitol, fructose, mannitol, rhamnose, trehalose, and xylose (Table 1). They do not utilize certain substrates as single carbon or single nitrogen and carbon sources and do not tolerate hydroxylamine $(250 \mathrm{mg} / \mathrm{ml}), \mathrm{NaCl}(3 \%)$, and $\mathrm{NaNO}_{2}(0.1 \%)$. Their internal similarity level is $92.50 \%$. The strains possess mycolate types I, IV, and VI (Table 2).

The phylogenetic position of this organism, based on an evaluation of partial 16S rRNA sequences, is within the rapidly growing species of the genus Mycobacterium. The

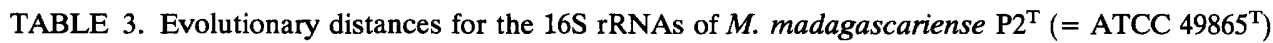
and various representatives of the fast-growing mycobacteria ${ }^{a}$

\begin{tabular}{|c|c|c|c|c|c|c|c|c|c|c|c|c|c|c|}
\hline \multirow[b]{2}{*}{ Organism } & \multicolumn{14}{|c|}{ Evolutionary distance from: } \\
\hline & $\begin{array}{l}\text { M. mad- } \\
\text { agascar- } \\
\text { iense }\end{array}$ & $\begin{array}{l}\text { M. con- } \\
\text { fluentis }\end{array}$ & $\begin{array}{c}\text { M. } \\
\text { phlei }\end{array}$ & $\begin{array}{l}\text { M. fla- } \\
\text { vescens }\end{array}$ & $\begin{array}{c}\text { M. smeg- } \\
\text { matis }\end{array}$ & $\begin{array}{c}\text { "M. } \\
\text { chro- } \\
\text { mogen" }\end{array}$ & $\begin{array}{l}\text { M. ther- } \\
\text { moresist- } \\
\quad \text { ibile }\end{array}$ & $\begin{array}{l}\text { M. neo- } \\
\text { aunum }\end{array}$ & $\begin{array}{l}\text { M. diern- } \\
\text { hoferi }\end{array}$ & $\begin{array}{c}\text { M. chu- } \\
\text { buense }\end{array}$ & $\begin{array}{c}M . \\
\text { obuense }\end{array}$ & $\underset{\text { gilvum }}{M .}$ & $\begin{array}{c}\text { M. } \\
\text { aurum }\end{array}$ & $\begin{array}{l}\text { M. vac- } \\
\text { cae }\end{array}$ \\
\hline M. confluentis & 1.9 & & & & & & & & & & & & & \\
\hline M. phlei & 3.0 & 2.9 & & & & & & & & & & & & \\
\hline M. flavescens & 3.2 & 3.5 & 2.2 & & & & & & & & & & & \\
\hline M. smegmatis & 1.6 & 1.7 & 2.6 & 1.2 & & & & & & & & & & \\
\hline "M. chromogen" & 3.0 & 3.0 & 2.1 & 2.1 & 2.0 & & & & & & & & & \\
\hline M. thermoresistibile & 3.2 & 3.3 & 3.2 & 3.0 & 2.2 & 2.0 & & & & & & & & \\
\hline$M$. neoaurum & 3.2 & 3.6 & 3.8 & 3.7 & 3.3 & 3.5 & 3.7 & & & & & & & \\
\hline M. diernhoferi & 3.1 & 3.9 & 4.8 & 4.4 & 3.2 & 4.4 & 4.0 & 1.8 & & & & & & \\
\hline M. chubuense & 3.2 & 3.5 & 3.5 & 3.6 & 2.8 & 4.0 & 4.4 & 4.0 & 3.9 & & & & & \\
\hline M. obuense & 2.9 & 3.5 & 4.0 & 3.6 & 2.0 & 4.5 & 4.6 & 3.1 & 2.9 & 1.7 & & & & \\
\hline M. gilvum & 3.1 & 3.6 & 3.4 & 2.9 & 2.8 & 3.8 & 3.9 & 3.3 & 2.8 & 1.9 & 2.0 & & & \\
\hline M. aurum & 4.3 & 5.0 & 4.5 & 4.0 & 4.0 & 4.7 & 5.2 & 3.8 & 3.9 & 2.5 & 3.1 & 3.0 & & \\
\hline M. vaccae & 2.9 & 2.8 & 4.1 & 3.6 & 3.2 & 4.3 & 3.7 & 3.6 & 3.8 & 3.0 & 3.1 & 2.7 & 3.0 & \\
\hline M. kommossense & 3.0 & 3.2 & 3.6 & 3.6 & 2.8 & 4.4 & 4.3 & 3.3 & 3.3 & 2.6 & 2.2 & 2.7 & 3.2 & 3.5 \\
\hline
\end{tabular}

${ }^{a}$ For the accession numbers of the 16S rRNAs of the reference strains, see reference 18 . 


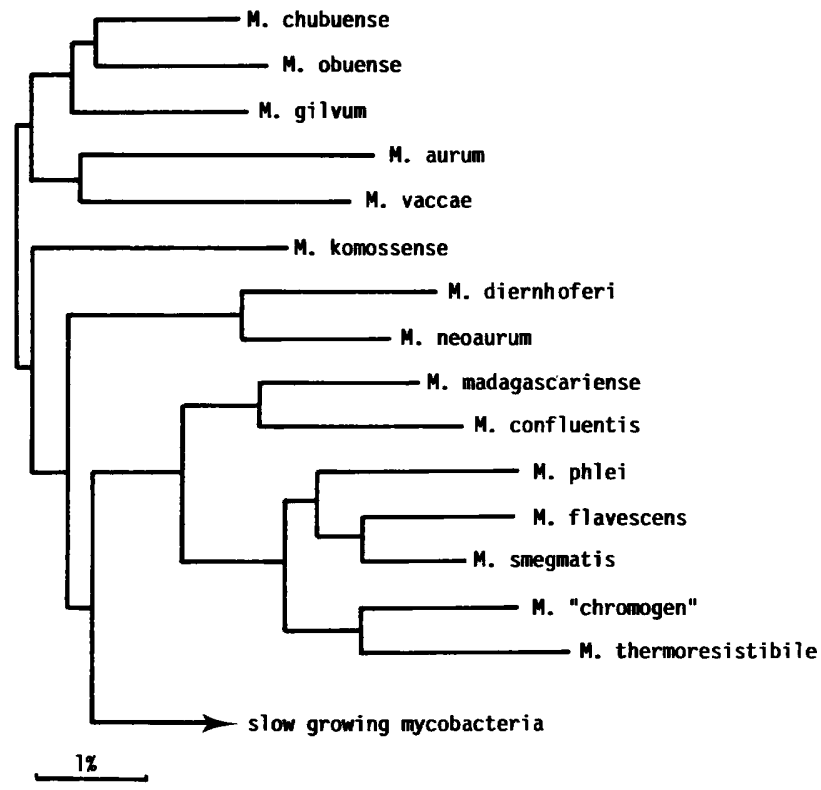

FIG. 1. Phylogenetic position of $M$. madagascariense $\mathrm{P}^{\mathrm{T}}$ (= ATCC $49865^{\mathrm{T}}$ ) within the radiation of the fast-growing mycobacteria. A more detailed branching pattern for the slow- and fastgrowing mycobacteria is given in reference 18 . The horizontal components of the branch lengths are proportional to evolutionary distances. Bar $=1 \%$ nucleotide differences.

strains are not pathogenic for rabbits, guinea pigs, and mice. The type strain of $M$. madagascariense strain is $\mathrm{P} 2$; a culture of this strain has been deposited in the American Type Culture Collection as strain ATCC 49865. Strains of $M$. madagascariense have been isolated from three different sphagnum biotopes in Madagascar.

Characteristics which differentiate $M$. madagascariense from other related mycobacteria. $M$. madagascariense can be easily differentiated from $M$. aurum by its failure to grow at $37^{\circ} \mathrm{C}$, by its failure to grow on media containing sodium fumarate, sodium succinate, or sodium citrate as a single carbon source or trimethylene diamine as a single nitrogen and carbon source, by its failure to grow in the presence of $0.1 \% \mathrm{NaNO}_{2}$, and by its failure to split sodium salicylate. Furthermore, $M$. madagascariense possesses acid phosphatase and arylsulfatase activities and produces acid from dulcitol and rhamnose, properties which are negative in $M$. aurum. The 16S rRNA sequences of the two organisms are also markedly different. $M$. madagascariense can be differentiated from $M$. obuense by its failure to grow at $37^{\circ} \mathrm{C}$, by its failure to grow in media containing sodium fumarate, sodium succinate, or propanol as a single carbon source, by its failure to grow in the presence of $3 \% \mathrm{NaCl}$ and $0.1 \%$ $\mathrm{NaNO}_{2}$, and by its failure to produce acid from galactose. $M$. madagascariense possesses acid phosphatase and arylsulfatase activities, hydrolyzes Tween, and produces acid from dulcitol and rhamnose, properties which are negative in $M$. obuense. Furthermore, there are important differences in the 16S rRNA sequences of these two species.

\section{ACKNOWLEDGMENTS}

This work was supported by grants from the German Leprosy Relief Association, Würzburg, Germany, and from the Federal Ministry for Research and Technology, Bonn, Germany.
We thank Hilde Hahn, Cornelia Rodde, Elke Link, and Werner Mohr for their skillful technical assistance.

\section{REFERENCES}

1. Bönicke, R. 1961. Die Bedeutung der Acylamidasen für die Identifizierung und Differenzierung der verschiedenen Arten der Gattung Mycobacterium. Jahresber. Borstel 5:7-87.

2. Bönicke, R. 1962. Identification of mycobacteria by biochemical methods. Bull. Int. Union Tuberc. 32:13-68.

3. Bönicke, R., and H. Nolte. 1967. Diamin-oxydasen in Mykobakterien. Zentralbl. Bakteriol. Parasitenkd. Infektionskr. Hyg. Abt. 1 Orig. 202:479-487.

4. Daffé, M., M. Lanelle, C. Asselineau, V. Lévy-Frébault, and H. L. David. 1983. Interêt taxonomique des acides gras des mycobactéries. Proposition d'une méthode d'analyse. Ann. Microbiol. (Paris) 1334B:241-256.

5. De Soete, G. 1983. A least squares algorithm for fitting additive trees to proximity data. Psychometrika 48:621-626.

6. Gordon, R. E., D. A. Barnett, H. E. Handerhan, and C. Hor-Nay Pang. 1974. Nocardia coeliaca, Nocardia autotrophica, and the Nocardin Strain. Int. J. Syst. Bacteriol. 24:54-63.

7. Gordon, R. E., and M. M. Smith. 1953. Rapidly growing acid-fast bacteria. I. Species description of Mycobacterium phlei Lehmann and Neumann. J. Bacteriol. 66:41-48.

8. Jukes, T. H., and C. R. Cantor. 1969. Evolution of protein molecules, p. 21-132. In H. N. Munro (ed.), Mammalian protein metabolism. Academic Press, New York.

9. Käppler, W. 1978. Zur Differenzierung von Mykobakterien mit dem Phosphatase Test. Beitr. Klin. Tuberk. Spezif. Tuberk. Forsch. 130:223-226.

10. Kirschner, P., A. Teske, K.-H. Schröder, R. M. Kroppenstedt, J. Wolters, and E. C. Böttger. 1992. Mycobacterium confluentis sp. nov. Int. J. Syst. Bacteriol. 42:257-262.

11. Kubica, G. P., and A. L. Ridgon. 1961. The arylsulfatase activity of acid-fast bacilli. III. Preliminary investigation of rapidly growing acid-fast bacilli. Am. Rev. Respir. Dis. 83:737-740.

12. Lévy-Frébault, V., M. Daffé, E. Restrapro, F. Grimont, P. A. Grimont, and H. L. David. 1986. Differentiation of Mycobacterium thermoresistibile from Mycobacterium phlei and other rapidly growing mycobacteria. Ann. Inst. Pasteur Microbiol. 173A:143-151.

13. Luqin, M., V. Auslina, F. Lopez Catahorra, F. Belda, M. Garcia Burce, C. Celma, and G. Prats. 1991. Evaluation of practical chromatographic procedures for identification of clinical isolates of mycobacteria. J. Clin. Microbiol. 29:120-130.

14. Meissner, G. 1959. Untersuchungen an atypischen Mykobakterien. II. Vergleichende tierexperimentelle Untersuchungen zur Frage Pathogenität und Virulenz. Beitr. Klin. Tuberk. Spezif. Tuberk. Forsch. 121:365-380.

15. Minnikin, D. E., S. M. Minnikin, J. H. Parlett, M. Goodfellow, and M. Magnusson. 1984. Mycolic acid patterns of some species of Mycobacterium. Arch. Microbiol. 139:225-231.

16. Müller, H.-J., K. Müller, J. Kazda, and K. H. Schröder. 1991. Zum Vorkommen von Mykobakterien in der Sphagnum-Vegetation von Madagaskar. Telma 21:213-219.

17. Pattyn, S. R., and F. Portaels. 1972. Identification and clinical significance of mycobacteria. Zentralbl. Bakteriol. Parasitenkd. Infektionskr. Hyg. Abt. 1 Orig. Reihe A 219:114-140.

18. Pitulle, C., M. Dorsch, J. Kazda, J. Wolters, and E. Stackebrandt. 1992. Phylogeny of rapidly growing members of the genus Mycobacterium. Int. J. Syst. Bacteriol. 42:337-343.

19. Sokal, R. R., and P. H. A. Sneath. 1963. Principles of numerical taxonomy. W. H. Freeman and Co., San Francisco.

20. Szabo, J., and E. Vandra. 1963. Mycobacterium minetti (Penso et al. 1952). Bacteriological and epidemiological observation. Acta Microbiol. Acad. Sci. Hung. 10:215-223.

21. Tsukamura, J., and S. Tsukamura. 1968. Differentiation of mycobacteria by susceptibility to nitrite and propylene glycol. Am. J. Respir. Dis. 98:505-506.

22. Tsukamura, M. 1965 . Differentiation of mycobacteria by susceptibility to hydroxylamine and 8-azaguanine. J. Bacteriol. 90:556-557. 
23. Tsukamura, M. 1965. Salicylate degradation test for differentiation of Mycobacterium fortuitum from other mycobacteria. J. Gen. Microbiol. 41:309-315.

24. Tsukamura, M. 1967 . Identification of mycobacteria. Tubercle 48:311-338.

25. Tsukamura, M. 1967. Differentiation of mycobacteria by utili- zation of nitrogen compounds and carbon source. Am. J. Respir. Dis. 95:307-310.

26. Valers-Guillén, P. L., and F. Martin-Luengo. 1986. 1-Tetradecanol, a new alcohol found in cell wall of some rapidly growing chromogenic mycobacteria. FEMS Microbiol. Lett. 35:59-63. 